
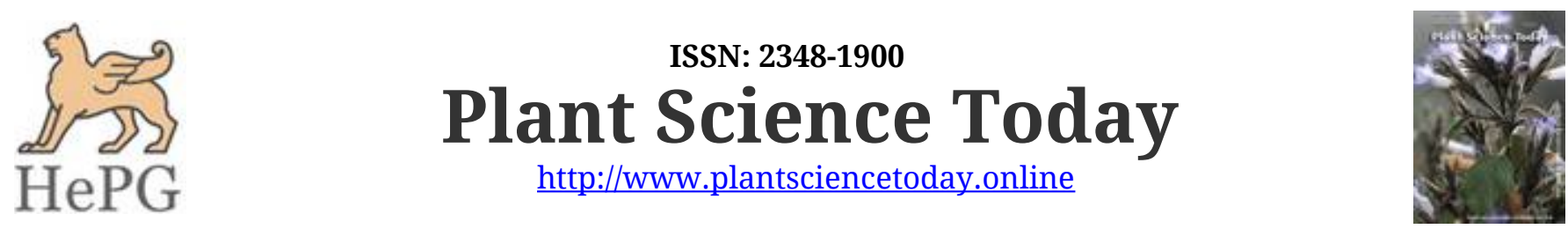

OPEN 6 ACcess

Review Article

\title{
Ethnobotanical and pharmacological importance of Taxus wallichiana Zucc.
}

\author{
Dwaipayan Sinha \\ Department of Botany, Government General Degree College, Mohanpur, Paschim Medinipur, West Bengal 721 436, India
}

\section{Article history}

Received: 12 October 2019

Accepted: 15 December 2019

Published: 08 February 2020

\section{Publisher}

Horizon e-Publishing Group

\author{
*Correspondence \\ Dwaipayan Sinha \\ \dwaipayansinha@hotmail.com
}

\begin{abstract}
Taxus wallichiana Zucc. or the Himalayan Yew is a gymnosperm growing along the Himalayan region of Indian and adjoining countries. The plant is extensively used by local people for treatment of various diseases such as fever, headache, diarrhea, fractures, problems of nervous system etc. It also finds usage in Unani system of medicine. The plant is rich in various bioorganic compounds natural products such as hydrocarbons, terpene alcohols, terpenoids (including taxoids), organic acids etc. The plant has been explored for anti-inflammatory, analgesic, antipyretic, anticonvulsant, immunomodulatory, hepatoprotective and anticancer activity with satisfactory outcome. The pharmacological activity of the plant is largely due to the presence of large number of terpenoids. The bioactive constituents present in the plant interacts with a large number of biochemical pathways involved in inflammatory processes, cell division cycles and inhibits a number of enzymes to bring about its protective action against various diseases. In this review, an attempt have been made to highlight the beneficial properties of Taxus wallichiana in various levels of usage starting from its fundamental ethnobotanical use to pharmacological use involving both in-vitro and in-vivo studies. Insights into the molecular mechanisms of action of the active constituents in bringing about the beneficial activity have also been illustrated. The plant can very well become a source of medicine for better management of a large number of diseases including cancer.
\end{abstract}

Keywords: Taxus wallichiana; terpenoids; cancer; anti-inflammatory; Taxol

Citation: Sinha D. Ethnobotanical and pharmacological importance of Taxus wallichiana Zucc. Plant Science Today 2020;7(1):122-134. https://doi.org/10.14719/pst.2020.7.1.636

Copyright: ( ) Sinha D (2020). This is an open-access article distributed under the terms of the Creative Commons Attribution License, which permits unrestricted use, distribution, and reproduction in any medium, provided the original author and source are credited (https://creativecommons.org/licenses/by/4.0/).

Indexing: Plant Science Today is covered by Scopus, Web of Science, BIOSIS Previews, ESCI, CAS, AGRIS, UGC-CARE, CABI, Google Scholar, etc. Full list at http://www.plantsciencetoday.online

\section{Introduction}

The Himalayan region has been a rich source of medicinal plants for millions of population inhabiting in around the mountain ranges. The Himalayan region is rich in floral diversity and plants are extensively used by local people for their daily needs ranging from thatching and shelter, fuel, fodder, house hold items, medicines $(1,2)$. The Indian Himalayan region presently houses
8000 species of vascular plants of which 1748 are known to possess medicinal properties (3). Himalayan mountains are home of 232 families of angiosperms representing 2302 genera and 10452 species while the gymnosperms are represented by 8 families, 20 genera and 51 species (4). Taxus wallichiana is one such gymnosperm that grows in the Himalayan region. It is a small to medium sized evergreen tree with a height of $10 \mathrm{~m}$ to $28 \mathrm{~m}$ (5). The plant is widely distributed in Asia and its 
occurrence spans from Afghanistan in the west to Philippines in the east and widely distributed in Himalayan regions of India and adjoining countries (6).

T. wallichiana is traditionally used by local people of Indian subcontinent for the cure of a number of ailments. In India, tincture prepared from aerial part of the plant is traditionally used for treatment of several diseases of central nervous system such as hysteria, grittiness, biliousness, epilepsy and nervousness. The plant also forms one of the components of the popular unani drug 'Zarnab' which is known to possess sedative and aphrodisiac properties (7). $T$. wallichiana is also used indigenously by people of Nepal for curing respiratory problems, bronchitis and cancer (8). The leaves of $T$. wallichiana is also used to prepare herbal tea for cure of epilepsy and indigestion (9). T. wallichiana is also reported to have immunomodulatory, anti-bacterial, antifungal, analgesic, anti-pyretic and anti-convulsant activities (10). Thus, based on the available reports, an attempt has been made to review the entire domain of beneficial properties of $T$. wallichiana with special emphasis on its chemical constituents, ethnobotanical uses and pharmaceutical applications.

\section{Methodology}

Extensive literature survey have been done using internet with PubMed, google scholar forming the search platform. Relevant research papers and review articles were selected in framing the article. The entire review article has been divided into an introductory phase which briefly describes geographical distribution, morphological features and taxonomic classification of Taxus wallichiana. Introductory segment is followed by detailed account of ethnobotanical uses of the plant. The article then extends into further insights into the chemical constituents of the plant and pharmacological uses and culminates with the discussion and conclusive remarks on the mode of action of the active principles in bringing about the pharmacological activities. The chemical structures have been drawn using ACD/Chem sketch Freeware 2018.2.5.

\section{Results}

\section{Geographical distribution}

Taxus wallichiana grows throughout the Himalayan region. In India it is widely distributed in the temperate zone of Himalayan mountains between altitudes of $1800 \mathrm{~m}$ to $3300 \mathrm{~m}$ above mean seal level (11). It is a slow growing understory species occurring in forests of Indian Himalayas and grows with Abies pindrow, Quercus semecarpifolia, Q. floribunda, Q. leucotrichophora, Betula utilis, Acer caesium, Pinus wallichiana,
Rhododendron arboreum and Betula alnoides (12). In the eastern Himalayas, the species grows in moist temperate zones at an altitude between 1600 to 2700 meters in West Kameng, Tawang, Lohit and Dibang Valley districts of Arunachal Pradesh (13). The plant also grows in hilly regions of Manipur and Meghalaya in north-eastern India (14). In Nepal, the plant is found in Rasuwa, Kavre, Kaski, Gorkha, Dolakha, Sindhupalanchok, Lamjung, Myagdi, Sakhuwasabha, Taplejung and Katmandu districts (15). It is also found in the Kanchenjunga landscape, a region of eastern Nepal (parts of Taplejung, Panchthar, Ilam and Jhapa districts), Sikkim and North Bengal (Darjeeling and Jalpaiguri, and recently formed Alipurduar and Kalimpong districts) in India, and western Bhutan (portions of Haa, Chukha, Samtse, Dagana and Paro districts) (16). In Pakistan, the plant is present in Murree hills, Hazara, Swat, Dir, Chitral as undergrowth of other conifers and broad leaved deciduous plants (17). It is also reported from Gilgit-baltistan and also in SWAT valley on the foot hills of Hindukhush range in Pakistan $(18,19)$.

\section{Description of the plant}

Taxus wallichiana is a dioecious tree species (20). The stems are fluted with spreading branches. The barks are thin, reddish brown and scale like (21). Leaves dark grey in colour, glossy green above, paler beneath, linear, $2-3.8 \times 0.3 \mathrm{~cm}$ in length, coriaceous, flattened, arranged in two vertical opposite rows. Cones are axillary and sessile. Male cones are solitary, axillary, sub-globose, bracts empty, with ten stamens. Female cones are solitary with few imbricate scales surrounding an erect ovule. Ovules are surrounded at base by membranous cup shaped disc. Fruit have bright red disc (Fig 1), succulent, enlarged, $7-8 \mathrm{~mm}$ in length. Seeds are olive-green in colour. Seeds dispersed by birds and animals. Growth of the trees are extremely low with 12-14 annual rings per $2.5 \mathrm{~cm}$ radius and girth increment 0.4 to $1.3 \mathrm{~cm}$ per year (22).

\section{Taxonomic hierarchy (IUCN Taxonomic hierarchy)}

Kingdom: Plantae

$$
\text { Division: Tracheophyta }
$$

Class: Coniferopsida

Order: Coniferales

Family: Taxaceae

Genus: Taxus

Species: wallichiana (23)

Synonym: Taxus baccata L. ssp. Wallichiana Zucc. Pilg. 


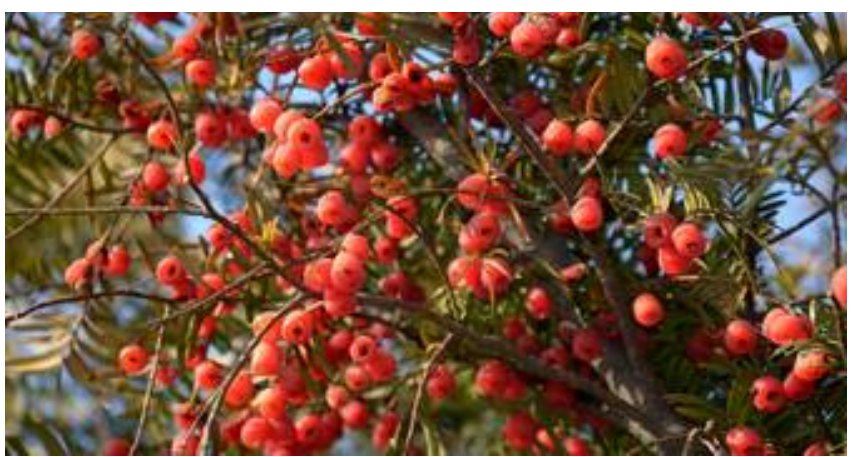

Fig 1. Picture of Taxus wallichiana Zucc. showing ripe female fructification (24)

\section{Population and Conservation status}

Populations of Taxus wallichiana were existent in Himalayan regions since $3 \mathrm{Ma} \mathrm{BP}(25)$. The plant is traditionally and extensively used by the locals of Himalayan region largely for primary healthcare purpose $(26,27)$. This has resulted in unregulated and unscientific harvesting of the plant ultimately leading to the decline and fragmentation of populations (28). The plant is thus marked as 'Endangered' in IUCN redlist with a continuous decrease in population (29). The plant is also included in CITES and negative list of exports of the government of India (30).

\section{Ethnobotanical uses}

Taxus wallichiana has been a plant of immense ethnobotanical use amongst the local people dwelling in the Himalayan region. They largely use $T$. wallichiana to cure various diseases. The various ethnobotanical use of $T$. wallichiana across various regions of Himalaya has been compiled in Table 1.

Table.1 Ethnobotanical use of Taxus wallichiana Zucc. across various Himalayan regions

\begin{tabular}{|c|c|c|c|c|}
\hline \# & Region & $\begin{array}{l}\text { Vernacula } \\
\text { r Name }\end{array}$ & Ethnobotanical uses & Ref. \\
\hline & $\begin{array}{l}\text { Asi Ganga sub } \\
\text { basin, } \\
\text { Uttarakhand, } \\
\text { India }\end{array}$ & Thuner & $\begin{array}{l}\text { Bark and seed extract with warm } \\
\text { water is given orally for } \\
\text { treatment of internal wound. }\end{array}$ & $(31)$ \\
\hline & $\begin{array}{l}\text { Urgam valley, } \\
\text { Chamoli } \\
\text { Garhwal, } \\
\text { Uttarakhand, } \\
\text { India }\end{array}$ & Thuner & $\begin{array}{l}\text { Bark extract is used as tea for } \\
\text { treatment of high blood } \\
\text { pressure. }\end{array}$ & $(32)$ \\
\hline & $\begin{array}{l}\text { Nanda Devi } \\
\text { Biosphere } \\
\text { Reserve, } \\
\text { Uttarakhand, } \\
\text { India }\end{array}$ & Thuner & $\begin{array}{l}\text { Bark used as a substitute of tea. } \\
\text { The powdered bark is used for } \\
\text { the treatment of cold. }\end{array}$ & (33) \\
\hline & $\begin{array}{l}\text { Kedarnath } \\
\text { wildlife } \\
\text { sanctuary, } \\
\text { Garhwal } \\
\text { Himalayas, } \\
\text { Uttarakhand, } \\
\text { India }\end{array}$ & & $\begin{array}{l}\text { Bark and bark paste used for the } \\
\text { treatment of fractured bones, } \\
\text { headache, breast piles }\end{array}$ & (34) \\
\hline & $\begin{array}{l}\text { Niti Valley, } \\
\text { Uttarakhand, } \\
\text { India }\end{array}$ & Thuner & $\begin{array}{l}\text { Dry powder of bark with salt and } \\
\text { ghee is mixed with water to } \\
\text { make tea and used for treatment } \\
\text { of high blood pressure and } \\
\text { cancer. } \\
\text { Paste of bark with egg yolk is } \\
\text { used as plaster for treatment of } \\
\text { fracture. }\end{array}$ & (35) \\
\hline & Jakholi Block, & Thuner & Juice of leaves are used for the & $(36)$ \\
\hline
\end{tabular}

\begin{tabular}{|c|c|c|c|}
\hline $\begin{array}{l}\text { Rudraprayag } \\
\text { district, } \\
\text { Uttarakhand, } \\
\text { India } \\
\end{array}$ & & $\begin{array}{l}\text { treatment of boils, cuts and } \\
\text { wounds }\end{array}$ & \\
\hline $\begin{array}{l}\text { 7. Mornaula } \\
\text { Reserve forest, } \\
\text { Kumaon, } \\
\text { Uttarakhand, } \\
\text { India }\end{array}$ & Thuner & $\begin{array}{l}\text { Bark, oil and leaves are used for } \\
\text { treatment of cancer. Bark is also } \\
\text { used as fuel. }\end{array}$ & (37) \\
\hline $\begin{array}{l}\text { 8. Shimla Hills, } \\
\text { Himachal } \\
\text { Pradesh, India }\end{array}$ & $\begin{array}{l}\text { Thuno, } \\
\text { Barmi }\end{array}$ & $\begin{array}{l}\text { Tincture from young shoots are } \\
\text { used for treatment of headache, } \\
\text { giddiness, feeble and falling } \\
\text { pulse, diarrhoea and severe } \\
\text { biliousness. Leaves are } \\
\text { antispasmodic and used for } \\
\text { treatment of nervousness, } \\
\text { hysteria, epilepsy and stones. }\end{array}$ & (38) \\
\hline $\begin{array}{l}\text { 9. Manali wildlife } \\
\text { sanctuary, } \\
\text { Himachal } \\
\text { Pradesh }\end{array}$ & Rakhal & $\begin{array}{l}\text { Barks and leaves are used for } \\
\text { treatment of cancer, swelling } \\
\text { and as contraceptive. }\end{array}$ & (39) \\
\hline $\begin{array}{l}\text { 10. Pabbar Valley, } \\
\text { Himachal } \\
\text { Pradesh }\end{array}$ & Thuna & $\begin{array}{l}\text { Tea prepared from needle and } \\
\text { bark are used for treatment of } \\
\text { congestion and cough. }\end{array}$ & $(40)$ \\
\hline $\begin{array}{l}\text { 11. Mandi and } \\
\text { Hamirpur } \\
\text { district, } \\
\text { Himachal } \\
\text { Pradesh }\end{array}$ & $\begin{array}{l}\text { Rakhala/ } \\
\text { Talispatra }\end{array}$ & $\begin{array}{l}\text { Tea prepared from barks and } \\
\text { leaves are used to treat asthma. } \\
\text { Bark is used for the treatment of } \\
\text { cancer. }\end{array}$ & (41) \\
\hline $\begin{array}{l}\text { 12. Churah } \\
\text { subdivision, } \\
\text { District } \\
\text { Chamba, } \\
\text { Himachal } \\
\text { Pradesh, India } \\
\end{array}$ & $\begin{array}{l}\text { Nadgaun/ } \\
\text { Brahmi }\end{array}$ & Bark is used as flavouring agent. & (42) \\
\hline $\begin{array}{l}\text { 13. Shimla water } \\
\text { catchment } \\
\text { sanctuary, } \\
\text { Himachal } \\
\text { Pradesh, India } \\
\end{array}$ & Rakhal & $\begin{array}{l}\text { Leaves used to cure cancer. Bark } \\
\text { used for preparation of tea. }\end{array}$ & (43) \\
\hline $\begin{array}{l}\text { 14. Kathua, Jammu } \\
\text { \& Kashmir, } \\
\text { India }\end{array}$ & Barmi & $\begin{array}{l}\text { Decoction of leaves are used to } \\
\text { cure asthma, bronchitis, cough, } \\
\text { indigestion and epilepsy. }\end{array}$ & $\begin{array}{l}(44, \\
45)\end{array}$ \\
\hline $\begin{array}{l}\text { 15. Rajouri, } \\
\text { Jammu \& } \\
\text { Kashmir, India }\end{array}$ & Barmi & $\begin{array}{l}\text { Decoction of leaves are used to } \\
\text { cure asthma, bronchitis and } \\
\text { cough. }\end{array}$ & (46) \\
\hline $\begin{array}{l}\text { 16. Ganderbal, } \\
\text { Kashmir, India }\end{array}$ & & $\begin{array}{l}\text { Tea prepared from boiling bark } \\
\text { in water is used for cure of } \\
\text { asthma, giddiness, arthritis, } \\
\text { tumour growths. }\end{array}$ & (47) \\
\hline $\begin{array}{l}\text { 17. Bangus valley, } \\
\text { Kashmir, India }\end{array}$ & Postul & $\begin{array}{l}\text { Tea made from bark is used to } \\
\text { cure sickness in winter. }\end{array}$ & (48) \\
\hline $\begin{array}{l}\text { 18. Bandipora, } \\
\text { Jammu and } \\
\text { Kashmir, India }\end{array}$ & $\begin{array}{l}\text { Postul } \\
\text { /Brammi }\end{array}$ & $\begin{array}{l}\text { Bark extract is made into a tea } \\
\text { and is used for curing of asthma, } \\
\text { headache, giddiness, tumour } \\
\text { growths. }\end{array}$ & (49) \\
\hline $\begin{array}{l}\text { 19. Galliyat, NWFP, } \\
\text { Pakistan }\end{array}$ & Bermi & $\begin{array}{l}\text { Decoction of stem is used for } \\
\text { treatment of tuberculosis. }\end{array}$ & (50) \\
\hline $\begin{array}{l}\text { 20. Neelam valley, } \\
\text { Muzaffarabad, } \\
\text { Pakistan } \\
\text { occupied } \\
\text { Kashmir }\end{array}$ & Birmi & $\begin{array}{l}\text { Tea from leaves are used to cure } \\
\text { asthma and high fever. }\end{array}$ & (51) \\
\hline $\begin{array}{l}\text { 21. Leepa valley, } \\
\text { Muzaffarabad, } \\
\text { Pakistan } \\
\text { occupied } \\
\text { Kashmir } \\
\end{array}$ & Birmi & $\begin{array}{l}\text { Leaf and bark extract is used to } \\
\text { treat tumours. Decoction of leaf } \\
\text { with honey is used for the } \\
\text { treatment of hey fever, } \\
\text { flatulation, epilepsy and asthma. }\end{array}$ & (52) \\
\hline $\begin{array}{l}\text { 22. Kel, Pakistan } \\
\text { occupied } \\
\text { Kashmir }\end{array}$ & & $\begin{array}{l}\text { Decoction of bark is used for } \\
\text { treatment of cancer. }\end{array}$ & (53) \\
\hline $\begin{array}{l}\text { 23. Shogran valley, } \\
\text { Pakistan }\end{array}$ & & $\begin{array}{l}\text { Plant used for the treatment of } \\
\text { cancer, cardiac disorders, head } \\
\text { ache, renal disorders and } \\
\text { digestive disorders. The plant is } \\
\text { antispasmodic, purgative and } \\
\text { antirheumatic. }\end{array}$ & (54) \\
\hline $\begin{array}{l}\text { 24. Manaslu, } \\
\text { Sagarmatha } \\
\text { and } \\
\text { Kanchenjunga } \\
\text { region, Nepal }\end{array}$ & & $\begin{array}{l}\text { Used for treatment of cancer and } \\
\text { jaundice. }\end{array}$ & (55) \\
\hline
\end{tabular}


Table 2. Major constituents of different plant parts of Taxus wallichiana Zucc

\begin{tabular}{|c|c|c|c|}
\hline Plant Parts & $\begin{array}{l}\text { Nature of } \\
\text { Compounds }\end{array}$ & Name of Compound & Ref. \\
\hline \multirow{7}{*}{$\begin{array}{l}\text { Essential } \\
\text { oil from } \\
\text { leaves }\end{array}$} & Alkane & n-Eicosane; Docosane ; n-Pentacosane. & \multirow{7}{*}{ (67) } \\
\hline & Alkene & Santolinatriene. & \\
\hline & Alcohol & $\begin{array}{l}\text { Geraniol; Globulol; Eugenol; Myrtenol; (E)-Verbenol; n-Hexenol; (Z)-3-Hexenol; (E)-2- } \\
\text { Hexenol; n-Hep-tan-2-ol; 1-Hepten-3-ol; (E)-2-Octen-1-ol; (Z)-2-Octen-1-ol; (E)-2-Nonenol; } \\
\text { 1-Octanol. }\end{array}$ & \\
\hline & Aldehyde & $\begin{array}{l}\text { Benzaldehyde; Anisaldehyde; n-Heptanal; n-Octanal; (E)-2-Octenal; n-Nonanal; (E)-2- } \\
\text { Nonenal; Dodecanal. }\end{array}$ & \\
\hline & Organic acids & Benzoic acid; Hexanoic acid. & \\
\hline & Organic acid esters & $\begin{array}{l}\text { ( Z)-3-Hexenyl formate; Octyl formate; (Z)-3-Hexenyl acetate; (E)-2-Hexenyl acetate; (E)-3- } \\
\text { Heptenyl acetate; Benzyl acetate; Anisyl acetate;n-Octyl acetate; Sabinyl acetate;(E)-2- } \\
\text { Hexenyl-n-hexanoate;Isopropyl-n-octanoate; (Z)-3-Hexenyl benzoate; Methyl benzoate; } \\
\text { Geranyl-n-heptanoate; Geranyl benzoate;n-Amyl anisoate; Geranyl tiglate; Methyl } \\
\text { salicylate. }\end{array}$ & \\
\hline & Terpenes & $\begin{array}{l}\text { a-Pinene; } \beta \text {-Pinene; Camphor; } \beta \text {-Caryophyllene; Caryophyllene oxide; (Z)- } \beta \text {-Ocimene; (Z)- } \\
\text { Sabinene hydrate; (Z)-Pinene hydrate. }\end{array}$ & \\
\hline \multirow[t]{7}{*}{ Leaves } & \multirow{7}{*}{$\begin{array}{l}\text { Taxoids } \\
\text { (terpenoids) }\end{array}$} & $\begin{array}{l}\text { Taxol; 10-deacetylbaccatin III; baccatin IV; 1-hydroxybaccatin I; 2'- } \\
\text { deacetoxydecinnamoyltaxinine J; 2'-deacetoxytaxinine J;2-acetoxybrevifoliol }\end{array}$ & $(68)$ \\
\hline & & Brevifoliol;2-acetoxybrevifoliol & $(68,69)$ \\
\hline & & $\begin{array}{l}\text { 5aO-(3'-dimethylamino-3'-phenylpropionyl) taxinine M;7-O-acetyltaxine A; 2a-acetoxy- } \\
\text { 2' } \beta \text {-deacetylaustrospicatine. }\end{array}$ & $(70)$ \\
\hline & & 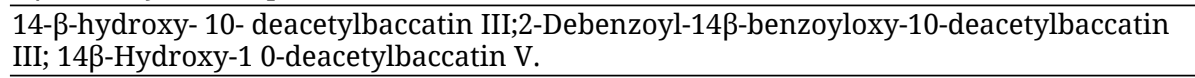 & $(71)$ \\
\hline & & $\begin{array}{l}\text { 19-debenzoyl-19-acetyltaxinineM; 13-deacetyltaxuspine A; 10-debenzoy1-2a- } \\
\text { acetoxybrevifoliol, }\end{array}$ & $(72)$ \\
\hline & & 2-deacetoxytaxinine B & (73) \\
\hline & & Wallifoliol; cephalomannine; 1-O-deacetylbaccatin 11 & (69) \\
\hline \multirow[t]{3}{*}{ Barks } & Ketone & 4-(4'-hydroxyphenyl)-2-butanone & \multirow{2}{*}{$(56)$} \\
\hline & Alcohol & 4-(4'-hydroxyphenyl)-2-butanol; 9-hydroxy-4,7-megastigmadiene-3-one-3-oxo-a-ionol & \\
\hline & $\begin{array}{l}\text { Taxoids } \\
\text { (Terpenoids) }\end{array}$ & $\begin{array}{l}\text { Taxayuntin E ; Taxayuntin G; Taxayuntin J; Taxinine A;2-Deacetoxy taxinine B; 2- } \\
\text { Deacetyl-5-decinnamoyl taxinine E;Taxinine J ; 2-Deacetoxy taxinine J ;5-Decinnamoyl } \\
\text { taxinine J; Taxinine M; 19-Debenzoyl-19-acetyl taxinine M; Taxchin A;Taxchin B; 1- } \\
\text { Hydroxy-5-deacetyl baccatin I; Baccatin III; Baccatin IV; 10,13-Deacetyl-abeobaccatin IV; } \\
\text { 1-Dehydroxy baccatin VI;13-Deacetyl baccatin VI;9-O-Benzoyl-9,10-dideacetyl (15-1)-abeo } \\
\text { baccatin VI;9-Benzoyl-9-deacetyl11(15-1)abeo baccatin VI Taxayunnanine C; 2'-Deacetyl } \\
\text { austrotaxine, 2-Acetoxy-2',7-dideacetoxy-1-hydroxy austrospicatine; 2-Acetoxy-2'- } \\
\text { deacetoxy austrospicatine; 2'-Deacetoxy austrospicatine; 7-Xylosyl-10-deacetyl taxol D; 7- } \\
\text { Xylosyl-10-deacetyl taxol;10-Deacetyl taxol; 7-Xylosyl taxol; 7-Xylosyl-10-deacetyl taxol C; } \\
\text { N-Methyl taxol C;10-Deacetyl epi-taxol; 7-Xylosyl taxol C; Epi-taxol; 2-Benzoyloxy-7,9,10, } \\
\text { 13-tetraacetoxy-4(20); 11 -taxadiene,2,5,9-Trihydroxy-10, 13-diacetoxy-4(20), 11-- } \\
\text { taxadiene; 5-Hydroxy-9,10-dia-cetoxy-13-oxo-4(20), 11-taxadiene; 2-Hydroxy-5,10,14- } \\
\text { triacetoxy 4(20), 11-taxadiene; 5,7,9,10,13-Pentaacetoxy 4(20), 11-taxadiene;7,9,10,13- } \\
\text { Tetraacetoxy-5-(3'-acetylamino3'-phenyl)propionyloxy-4(20), 11-taxadiene;Hydroxy- } \\
\text { triacetoxy-5(3'-dimethylamino-3'phenyl)propionyloxy4(20), 11- } \\
\text { taxadiene;Taxusin;Yunnanxane. }\end{array}$ & $(74)$ \\
\hline \multirow[t]{2}{*}{ Heart wood } & \multirow{2}{*}{ Taxoids } & Taxusin ; 7-xylosyl-10deacetyltaxol C. & $(75)$ \\
\hline & & 13-acetyl-13-decinnamoyltaxchinin. & (76) \\
\hline \multirow[t]{4}{*}{ Roots } & Taxoids & $\begin{array}{l}\text { Baccatin III; Baccatin IV; Taxusin; 1 } \beta \text {-hydroxybaccatin I; Penta acetoxy taxadiene 7; 7- } \\
\text { xyloxyl-10-deacetyl-taxol. }\end{array}$ & \multirow[t]{2}{*}{$(65)$} \\
\hline & Lignans & (-) Seco-isolariciresinol; Taxiresinol; Isotaxiresinol. & \\
\hline & Lignans & $\begin{array}{l}\text { a-Conidendrin; Formosanol; Methyl-a-Conidendral; a-Intermedianol;1, 4-methano-2- } \\
\text { benzoxepin-10-methanol, 1, 3, 4, 5-tetrahydro-7-hydroxy-5-(4-hydroxy-3methoxyphenyl)- } \\
\text { 8-methoxy. }\end{array}$ & \multirow[t]{2}{*}{$(66)$} \\
\hline & $\begin{array}{l}\text { Sesquiterpene } \\
\text { lactone }\end{array}$ & Cinnamolide. & \\
\hline \multirow[t]{2}{*}{ Seeds } & Triterpenoid & Ursolic acid. & \multirow[b]{2}{*}{ (77) } \\
\hline & $\begin{array}{l}\text { Cyanogenic } \\
\text { glucoside }\end{array}$ & Amygdalin. & \\
\hline
\end{tabular}

\section{Chemical constituents}

Taxus wallichiana has been a plant of extensive study due to its diverse ethnobotanical uses. The plant also exhibits a wide range of pharmacological properties and detailed investigations about the chemical constituents of the plant have been undertaken by a number of researchers. Essential oil is a major ingredient of 


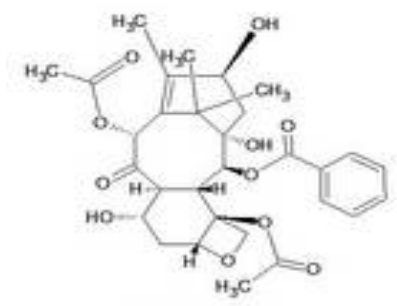

BACCATIN III

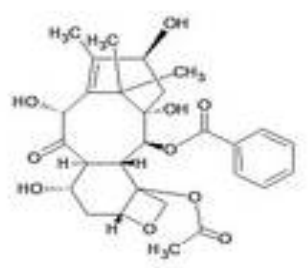

10- DEACETYL BACCATIN III

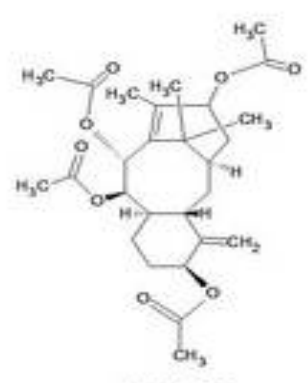

TAXUSIN

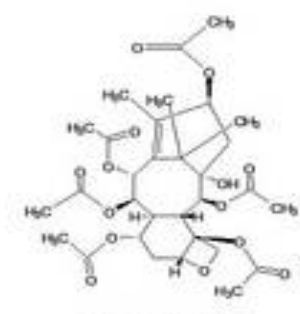

BACCATIN IV

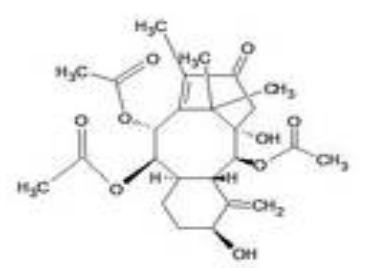

TAXININE A

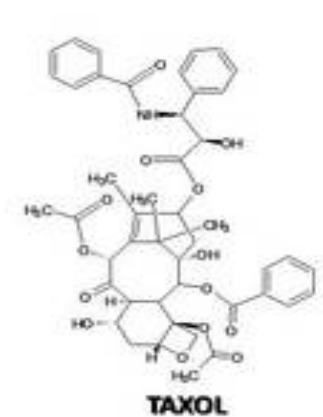

TAXOL

Fig 3. Chemical structures of selected Taxoids present in Taxus wallichiana Zucc.

leaves obtained through hydrodystillation process. The major constituents of essential oil are long chain hydrocarbons, terpene alcohols such as geraniol, globulol, eugenol, myrtenol and (E)verbenol. In addition to it, the essential oil also contains fatty alcohol such with varying chain length, aldehydes, organic acid esters and terpenes (56). These terpenes and terpene alcohols are largely responsible for the characteristic fragrance of essential oil (57). In addition to essential oils, all parts of $T$. wallichiana contains the most unique group of compound by the name taxoids or taxanes. These compounds are largely responsible for pharmacological activities of Taxus $(58,59)$. The taxoids are fundamentally diterpenoids and contains 6/8/6-membered ring skeleton known as taxane skeleton which is chemically a pentamethyl [9.3.1.0] 3, 8 tricyclopentadecane skeleton $(60,61)$.

The most important and pharmacologically important representative of the taxoids present in $T$. wallichiana is Taxol. The biogenesis of taxol involves the condensation of the three isoprenyl diphosphate (IPP) units with dimethylallyl diphosphate (DMAPP) both of which are produced either through mevalonic (MVA) pathway in the cytosol or via the methyl erythritol phosphate (MEP) pathway in plastids. The first determining step in the biogenetic pathway is cyclization of geranyl geranyl diphosphate (GGPP) to taxadiene followed by eight cytochrome P450-mediated oxygenations, three CoA-dependent acyl/aroyl
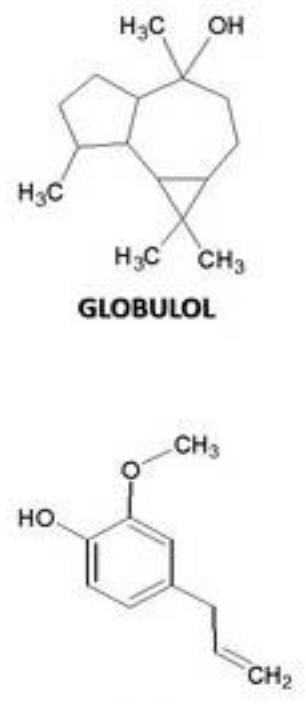

EUGENOL

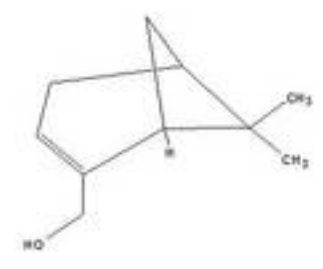

MYRTENOL

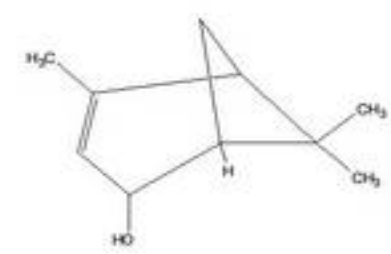

VERBENOL

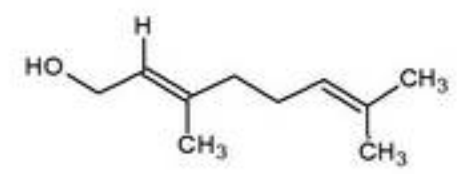

GERANIOL

Fig 4. Chemical Structure of selected alcohols present in Taxus wallichiana Zucc.

transfers, an oxidation at C9, and oxetane (D-ring) formation finally resulting in formation of intermediate baccatin III $(62,63)$ (Fig. 2). The final stage of taxol biosynthesis involves the assembly of C13 side chain appended to the Baccatin molecule (64). Analysis of bark, root and other parts of the plants revealed the presence of taxol, baccatins and other intermediary molecules and taxol analogues (Table 2). Apart from taxoids, T. wallichiana also contains lignans such as (-) seco-isolariciresinol, taxiresinol, isotaxiresinol, formasonol, sesqueterpene lactone, triterpenoid cyanogenic glucoside and phytosterols $(65,66)$. Chemical structures of selected compounds present in $T$. wallichiana is depicted in Figs. 2, 3 \& 4 respectively. Most of these compounds have been reported to have pharmacological importance and have been discussed in this article. The various compounds isolated from different parts of $T$. wallichiana are listed in Table 2.

\section{Pharmacological activities of Taxus wallichiana Zucc.}

\section{Anti-inflammatory activity}

Inflammation is associated with onset of a number of diseases including asthma (78), rheumatoid arthritis (79), atherosclerosis (80), chronic venous insufficiency (81), diabetes (82), cancer (83) etc. Herbal remedies have proven to be an effective way to reduce inflammatory processes (84). In the 
same line Taxus wallichiana have proven its efficacy to combat inflammatory processes. Taxusabietane A, isolated from $T$. wallichiana was reported to possess anti-inflammatory potential.

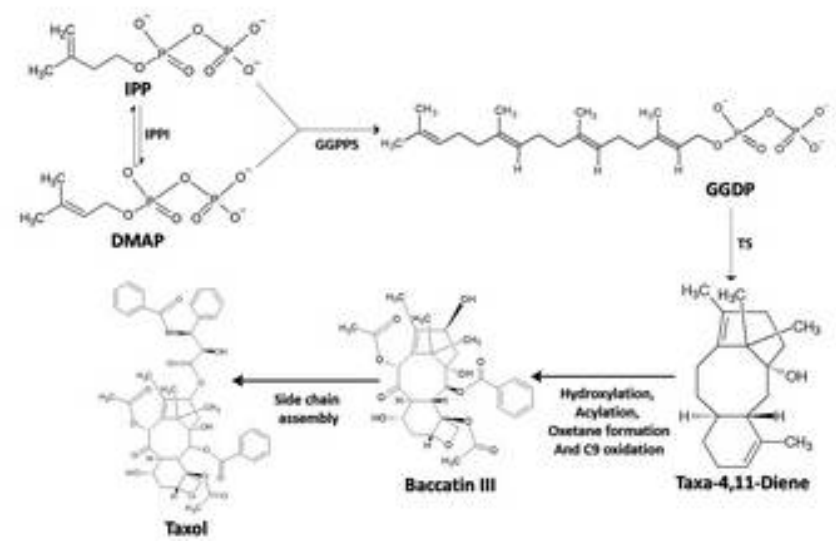

Fig 2. Schematic representation of major steps associated with biosynthesis of taxol

IPP: isopentenyldiphosphate

DMAPP: dimethylallyldiphosphate

GGDP: Geranylgeranyldiphosphate

IPPI: isopentenyldiphosphateisomerase

GGPPS: geranylgeranyldiphosphate synthase

TS: taxadiene synthase

The results obtained from a study indicated that taxusabietane A showed lipoxygenase inhibitory activity with an IC50 value of $57 \pm 0.31$ $\mu \mathrm{M}$ which was significant in relation to standard compounds baicalein and tenidap sodium with an $\mathrm{IC}_{50}$ value of $22.1 \pm 0.03$ and $41.6 \pm 0.02 \mu \mathrm{M}$ respectively. In addition to it, taxusabietane $\mathrm{A}$ at $5 \mathrm{mg} / \mathrm{kg}$ and $10 \mathrm{mg} / \mathrm{kg}$ dose also inhibited carrageenan induced oedema in adult wistar rats though in this case standard compound indomethacin at same dose exhibited comparatively better result (85). Another study reported that taxoids namely tasumatrol B, 1, 13diacetyl-10-deacetyl baccatin III (10-DAD) and 4deacetylbaccatin III (4-DAB), isolated from $T$. wallichiana is significantly effective in bringing down inflammations induced by carrageenan and cotton pellet in rats. At $20 \mathrm{mg} / \mathrm{kg}$ and $40 \mathrm{mg} / \mathrm{kg}$ of dose, the tested compounds showed significant inhibition of paw oedema in carrageenan induced inflammation model out of which tasumatrol B was observed to be most effective. In addition to it, cotton pellet test revealed that all the three test compounds showed inhibition against inflammation and granuloma accumulation (86). Two more abietane diterpenoids namely taxusabietane $\mathrm{C}$ and taxamairin $\mathrm{F}$ have also reported to show lipoxygenase inhibitory effect with $69 \pm 0.31$ and $73 \pm 0.14 \mu \mathrm{M}$, respectively (87).

\section{Analgesic, antipyretic and anticonvulsant activity}

The analgesic activity of tasumatrol $\mathrm{B}$, a taxane isolated from the bark of Taxus wallichiana have been reported, It has been observed that tasumatrol B administered at $40 \mathrm{mg} / \mathrm{kg}$ in wistar rats significantly decreased the writhing count in acetic acid writhing experiment (86). The analgesic activity of $T$. wallichiana was observed by the formalin test in rats. It was observed that upon treatment with 50, 100 and $200 \mathrm{mg} / \mathrm{kg}$ of the extract of $T$. wallichiana to rats previously injected with $0.05 \mathrm{ml}$ of formalin in the plantar surface of hind paw, the pain score severity showed a concentration dependent decline in both early and late phases of analgesia. In addition to it, the antipyretic activity was investigated by injecting $15 \%$ aqueous solution of yeast at $10 \mathrm{ml} / \mathrm{kg}$ dose to induce pyrexia. This was followed by intraperitoneal injection of 50, 100 and $200 \mathrm{mg} / \mathrm{kg}$ of extract. It was observed that all the dose of plant extract showed significant inhibition of pyrexia induced by yeast and the antipyretic effect of 200 $\mathrm{mg} / \mathrm{kg}$ of extract is comparable to $20 \mathrm{mg} / \mathrm{kg}$ of paracetamol between 30 and 60 minute of treatment. The anticonvulsant activity was also tested observing the effect of plant extracts on pentylenetetrazole induced seizers in rats. It was observed that pretreatment of 50,100 and $200 \mathrm{mg} /$ $\mathrm{kg}$ of plant extract significantly reduced mioclonous seizures. Additionally, 100 and $200 \mathrm{mg} /$ $\mathrm{kg}$ of extracts significantly delayed the onset of first clonous seizures while $200 \mathrm{mg} / \mathrm{kg}$ of extract delayed the tonous seizures. Extracts of all doses protected the rats from tonic-clonic seizures. Diazepam was used as a control and showed remarkable anticonvulsant activity at $7.5 \mathrm{mg} / \mathrm{kg}$. There was also a decrease in percentage of mortality in animals upon pretreatment with extracts (88).

\section{Hepatoprotective activity}

The protective action of methanolic extract of Taxus wallichiana against carbon tetrachloride induced hepatotoxicity in rats was reported from a recent study. It was observed that $\mathrm{CCl}_{4}$ treatment resulted in significant elevation of liver enzyme markers namely aspartate transaminase (AST), alanine transaminase (ALT) and lactate dehydrogenase (LDH). Treatment of animals with $1 \mathrm{ml}$ of 100 and $300 \mathrm{mg} / \mathrm{kg} / \mathrm{body}$ weight resulted in decrease in the levels of liver marker enzymes histopathological investigation of liver of rats treated with plant extracts revealed an almost normal hepatic architecture with less infiltration of fat and absence of necrosis all of which were prominent in rats treated with carbon tetrachloride (89).

\section{Immunomodulatory activity}

The immunomodulatory potential of Taxus wallichiana was investigated using human lymphocyte as the experimental system. In the experiment, cyclophosphamide was used to supress the proliferation of lymphocytes and this condition was reversed by cotreatment of 1hydroxy-2-deacetoxy-5-decinnamoyl-taxinine J (1 
$\mu \mathrm{g} / \mathrm{ml})$ with concanavaline A (5 $\mu \mathrm{g} / \mathrm{ml})$, an immune stimulant (90).

\section{Anticancer activity}

Some studies have been undertaken to investigate the anticancer potential of compounds isolated from Taxus wallichiana. A study reported that 1hydroxy-2-deacetoxy-5-decinnamoyl-taxinine J was cytotoxic to five cancer cell lines namely MCF7, WRL-68, KB, PA-1, Colo 320DM human cancer cell lines as determined by MTT and clonogenic assays (90). Another study have shown cytotoxicity of taxiresinol, a lignan isolated from heartwood of the plant against human liver, colon, ovarian and breast cancer cell lines (91). Taxawallin I, a new taxoid isolated from $T$. wallichiana has been reported to show toxicity against HepG2, A498, NClH226 and MDR 2780AD cancer cells (92). Another study reported isolation of four novel taxane derivatives namely N-debenzoyl-N-methyl-Nheptanoyl-taxol, N-debenzoyl-N-me-thyl-N-octanoyltaxol, N-debenzoyl-N-methyl-N-(4-methylhexanoyl)taxol, and N-debenzoyl-N-methyl-N-[(4Z)-1-oxo-4tenenoyl]-taxol from ethanol extract of whole plant. It is also reported that the taxanes were inhibitory towards MCF-7, A549, and 3-AO cancer cell lines and had microtubule stabilizing properties (93).

The term taxane or taxoids refers to all the terpenoid compounds having molecular structure based on baccatin unit, either obtained naturally from Taxus $s p$ or are semi synthetically or synthetically prepared exhibiting anticancer properties. Taxanes interacts with the microtubules involved in mitotic process. Taxanes stabilize the microtubules of cells which counteract their depolimerization. Thus, correct separation of two identical sets of chromosomes and their consequent transfer during cell division are inhibited resulting in blockage of cell mitosis ultimately leading to cell death (94). Taxanes promote microtubule polymerization and arrest mitosis through activation of spindle assembly check point and keeping a small number of unattached kinetochores to the microtubules. This delays mitotic metaphase progression and inhibits anaphase prompting complex (95). On a molecular level, binds to a pocket in $\beta$ - tubulin that faces microtubule lumen and is near the lateral interface between protofilaments thereby affecting normal function and cellular processes (96). The binding of Paclitaxel to $\beta$ - tubulin subunit results in stabilization of microtubules through induction of conformational changes of the M-loop of $\beta$ - tubulin which result in more stable lateral interaction between adjacent protofilaments thereby changing microtubule dynamics and inducing mitotic block and triggering apoptosis of cancer cells (97, 98).

Moreover, taxanes also exhibit apoptotic action interacting with various proteins and enzymes which are involved in cell cycle, apoptosis and cell death. Increased reactive oxygen species (ROS) is one of the earliest events of apoptosis and is brought about by taxanes (99). Taxanes also initiate decrease in mitochondrial membrane potential $(\Delta \Psi \mathrm{m})$ and induces opening of mitochondrial membrane permeability pore resulting in release of calcium and cytochrome c from mitochondria $(100,101)$. Caspases are the family of endoproteases that play an important role in cell inflammation and cell death (102). Taxanes also activates caspases thus initiating cell death and apoptosis (103). B-cell lymphoma (Bcl-2) is the key protein which regulates programmed cell death and apoptosis (104). They may be divided into two major groups namely (a) antiapoptotic protein (BCL-2, BCL-XL, MCL-1, BFL-1, BCL-W, and BCL2L10) and (b) proapoptotic proteins (BAK, BAX) (105). The apoptosis in cancer cells is further induced by phosphorylation and inactivation of antiapoptotic Bcl-2 by taxane (106). Along with Bcl-2, p53 also plays a major role in apoptotic process. It is an important tumour suppressor gene which regulates downstream expression of other genes involved in DNA repair, cell cycle arrest and apoptosis (107). Taxanes are reported to act as a p53 inducers thereby enhancing the apoptotic process (108). The p21 is an universal cyclin dependent kinase (CDK) inhibitor, controlled by p53 and physically interacts and inhibits cyclin-CDK2, cyclin-CDK1, cyclinCDK4/6 complexes thus regulates progression of cell cycle during G1 and S phases (109). Taxanes results in increase of expression p21 through upregulation of p53 (110).

\section{Toxicity}

Toxicity of Taxus sp is known to humans since early civilization. Juice of the plant was applied to arrows for hunting and leaves were used for homicide and suicide (111). The main active compounds of the plant include a mixture of diterpenoid alkaloids namely taxine $\mathrm{A}$ and $\mathrm{B}$, isotaxine $\mathrm{B}$, taxol $\mathrm{B}$ and are responsible for toxicity causing toxicity resulting in the occurrence of symptoms like nausea, vomiting, diffuse abdominal pain, tachycardia (initially) and convulsions, followed by bradycardia and respiratory muscle paralysis (112). The time from ingesting lethal dose of Taxus toxin to death usually varies between 2-5 hours with symptoms occurring between 30 minutes to 1 hour after ingestion (113). Generally, the Taxus toxins acts by generation of a block in the distal portion of the conduction system of the heart resulting in fatal arrhythmia (114). It is further reported from a study that taxine-B inhibits calcium and sodium transport in myocardial cells and interferes with heart's conducting system thereby acting as a cardiac depressant (115).

\section{Conservational approaches and production of bioactive compounds}

The population of Taxus wallichiana have taken a toll due to its ever increasing demand among the localites accompanied by high rate of collection. To make the things even more grave, the plant exhibits slow growth and poor regeneration (116). This has resulted in number of conservational 
approaches to save the population from extinction. Tissue culture method have been a versatile approach for mass propagation of a number of plants (117). The long dormancy period of the plant can overcome by culture of zygotic embryos which can develop into full grown seedlings in 1012 weeks (118). A study reported that shoot elongation and root induction through shoot tip culture is feasible and may be applicable for propagation of the plant (119). Another study reported regeneration of $T$. wallichiana plant via shoot organogenesis from callus cultures derived from zygotic embryos (120). Apart from tissue culture techniques, stem cuttings treated with growth promoting substances have also been proved effective for propagation of the plant (121). Another recent study reported that treatment of shoot cuttings of the plant with indole acetic acid (IAA), indole butyric acid (IBA) and napthoxy acetic acid (NAA) resulted in effective initiation of roots (122). Tissue culture techniques are not only used for mass propagation but also for the production of bioactive compounds. There have been reports that extracts from the cell cultures of the plant contains taxol, deacetyl baccatin III and baccatin III (123). Another study detected the presence of taxol $(0.8499 \%)$ in the callus culture (124). Use of bioreactors for production of taxol and baccatin III from suspension cultures have also been reported from a study (125).

\section{Discussion}

The genus Taxus or Yew holds immense importance globally from pharmacological point of view. A lot of research work have been undertaken to explore the pharmacological importance of the genus. The most important amongst them is exploration of Pacific Yew or Taxus brevifolia . Exploration on the antineoplastic activity of the active constituent of $T$. brevifolia started way back in 1960 (126). It consequently underwent a series of modifications and culminated in commercial production as Paclitaxel by Bristol-Myers Squibb (BMS) in the year 1992 (127). Since then there have been no stopping and a number of variants and semisynthetic analogues such as docetaxel and cabazitaxel were developed all of which possess same anticancer activity. Moreover, studies showed that extracts of European yew, Taxus baccata, also have the potential to inhibit Caov-4 and HeLa cancer cell lines (128). It is also reported from a study that the bark extract of $T$. baccata also possess anti inflammatory properties (129). There are also reports that the leaves of $T$. baccata also have bronchodilating properties and beneficial effect on asthma (130). Japanese Yew, Taxus cuspidata is also reported to possess inhibitory activity against MCF-7 (breast), PG and A549 (lung), PC-3M-1E8 (prostate), BGC-823 (gastric), WM451 (melanoma), Bel-7402 (hepatocellular), KB (oral squamous),
HeLa (cervical), and HL-60 (leukemic) cell lines (131).

Across the world there has been a growing demand of herbal medicines and $80 \%$ of the total population are relying on herbal remedies for primary healthcare (132). The figures are similar for Indian population of which $70 \%$ relies on plants as source of medicines (133). Now coming back to Himalayan Yew or Taxus wallichiana, it is reported that the plant finds extensive use by the people living in various location of Himalayas. The use of plant has been assimilated in their tradition and thus justifies its ethnobotanical and ethnomedicinal significance. Thus, there is a strong requirement for a reverse pharmacological process in which the traditional knowledge and usage pattern of Himalayan Yew can be better explored in the laboratory condition for validation of its pharmacological efficacy. In this regard, the plant has been investigated to some extent for a number of pharmacological activities which has yielded promising outcome. Thus, this species is at par with the other species of Taxus, many of which have been extensively investigated for their pharmacological actions. However most of the investigations have been made of cell lines or in animal systems. Experimentation using clinical trials using humans are further required for consequent development of drugs. Additionally, exploration of anticancer potential from Taxus sp has become a matter of priority since last 50 years and as mentioned earlier. Paclitaxel is a noble outcome of extensive research on T. brevifolia. In a similar manner, the Himalayan Yew can also be explored further for its anticancer potential leading to development and commercialization of drugs required for cancer treatment. In this aspect there are few reports of detection taxol in cell and callus culture of $T$. wallichiana. This avenue also needs further elaboration and investigation with a motive of increasing the concentration and yield of Taxol through modification of ambient culture condition. This would lead to a cost effective approach in the development of anticancer drugs from $T$. wallichiana.

Presently, over exploitation of $T$. wallichiana have resulted in its depletion. Isolation of population through habitat fragmentation leads to restriction of connectivity, resulting in low levels of gene flow between the population with subsequent lower genetic diversity and higher genetic differentiation in and among remaining populations (134). Moreover, smaller isolated populations also undergo frequent inbreeding which often express deleterious alleles leading to reduction in reproductive capacity and low offspring survival (135). Thus, studies on the genetic diversity of the plant is extremely relevant as an important avenue towards conservation as well an indicator of possible extinction. An important approach towards conservation of diminishing population of $T$. wallichiana is to 
maintain an effective population size so that the level of genetic variation can be maintained. Thus, proper planning and management of this species in their natural habitat will be extremely fruitful in harvesting pharmacologically active principles from the plant. Techniques of molecular biology and biotechnology should also be involved in the overall process of conservation.

\section{Conclusion}

Taxus wallichiana or Himalayan Yew is an endangered gymnosperm that grows in the Himalayan region and is of immense Ethnobotanical importance amongst the people. They contain huge amount of phenolics and terpenoids which forms the backbone of their medicinal potential. The plant has proven its efficacy from pharmacological point of view and can be very well utilised as a cost effective source of medicine for management of diseases of the people of Indian subcontinent. The bioprospection of this plant thus becomes extremely relevant for the benefit of humans.

\section{Acknowledgements}

The author is thankful to The Officer-in-Charge, Government General Degree College, Mohanpur, Paschim Medinipur for his constant encouragement and cooperation. The author is also thankful to American Centre Library, and The National Library, Kolkata for providing state of art electronic facilities and learning resources in framing the article.

\section{Conflict of Interest}

Author declares that he has no conflict of interest in the publication.

\section{References}

1. Rana D, Bhatt A, Lal B. Ethnobotanical knowledge among the semi-pastoral Gujjar tribe in the high altitude (Adhwari's) of Churah subdivision, district Chamba, Western Himalaya. J Ethnobiol Ethnomed.2019;15(1):10. https://doi.org/10.1186/s13002-019-0286-3

2. Pala NA, Sarkar BC, Shukla G, Chettri N, Deb S, Bhat JA, et al. Floristic composition and utilization of ethnomedicinal plant species in home gardens of the Eastern Himalaya. J Ethnobiol Ethnomed.2019;15(1):14. https://doi.org/10.1186/ s13002-019-0293-4

3. Joshi RK, Satyal P, Setzer WN. Himalayan Aromatic Medicinal Plants: A Review of their Ethnopharmacology, Volatile Phytochemistry, and Biological Activities. $\begin{array}{lll}\text { Medicines } & \text { (Basel). }\end{array}$ https://doi.org/10.3390/medicines3010006

4. Rana SK, Rawat GS. Database of Himalayan Plants Based on Published Floras during a Century. Data. 2017;2(4):36. https://doi.org/10.3390/data2040036.

5. Juyal D, Thawani V, Thaledi S, Joshi M. Ethnomedical properties of Taxus wallichiana Zucc. (Himalayan yew). J

\section{Tradit Complement https://doi.org/10.4103/2225-4110.136544 \\ Med.2014;4(3):159-61.}

6. Hussain A, Qarshi IA, Nazir H, Ullah I, Rashid M, Shinwari ZK. In-vitro callogenesis and organogenesis in Taxus wallichiana Zucc. The Himalayan Yew. Pak J Bot.2013;45(5):1755-59.

7. Sharma H, Garg M. Neuropharmacological activities of Taxus wallichiana bark in Swiss albino mice. Indian J Pharmacol.2015;47(3):299-303. http://dx.doi.org/10.4103/0253-7613.157128

8. Gaire BP, Subedi L. Medicinal Plant Diversity and their Pharmacological aspects of Nepal Himalayas. Phcog J.2011;3(25):6-17. https://doi.org/10.5530/pj.2011.25.2

9. Aboutabl ME. Antiepileptic drugs: progress and development. Egypt Pharmaceut J.2018;17(3):129-40.

10. Rahman S, Salehin F, Uddin MJ, Zahid A. Taxus Wallichiana Zucc. (Himalayan Yew): insights on its antimicrobial and pharmacological activities. OA Alternative Medicine.2013;1(1): 3.

11. Purohit A, Maikhuri RK, Rao KS, Nautiyal S. Impact of bark removal on survival of Taxus baccata L. (Himalayan yew) in Nanda Devi Biosphere Reserve, Garhwal Himalaya, India. Curr Sci.2001;81(5):586-90.

12. Pant S, Samant SS. Population Ecology of the Endangered Himalayan Yew in Khokhan Wildlife Sanctuary of North Western Himalaya for Conservation Management. J Mt Sci. 2008;5:257-64. https://doi.org/10.1007/s11629-008-0078-z

13. Nimasow G, Nimasow OD, Rawat JS, Tsering G, Litin T. Remote sensing and GIS-based suitability modeling of medicinal plant (Taxus baccata Linn.) in Tawang district, Arunachal Pradesh, India. Curr Sci.2016;110(2):219-27. https://doi.org/10.18520/cs/v110/i2/219-227

14. Patel P, Patel K, Gandhi T. Evaluation of Effect of Taxus baccata Leaves Extract on Bronchoconstriction and Bronchial Hyperreactivity in Experimental Animals. J Young Pharm.2011;3(1):41-47. https://doi.org/10.4103/0975-1483.76418

15. Poudel RC, Gao LM, Möller M, Baral SR, Uprety Y, Liu J, et al. Yews (Taxus) along the Hindu Kush-Himalayan region: exploring the ethnopharmacological relevance among communities of Mongol and Caucasian origins. J Ethnopharmacol.2013;147(1):190-203. https://doi.org/10.1016/j.jep.2013.02.031

16. Kandel P, Chettri N, Chaudhary RP, Badola HK, Gaira KS Wangchuk S, et al. Plant diversity of the Kangchenjunga Landscape, Eastern Himalayas. Plant Divers. 2019; 41(3):153-65. https://doi.org/10.1016/j.pld.2019.04.006

17. Chaudhri II, Distribution of gymnosperms in West Pakistan.Vegetatio.1963;11(5-6):372-82.

18. Ismail I, Sohail M, Gilani H, Ali A, Hussain K, Hussain K, et al. Forest inventory and analysis in Gilgit-Baltistan A contribution towards developing a forest inventory for all Pakistan. International Journal of Climate Change Strategies and Management.2018;10(4):616-31. https://doi.org/10.1108/IJCCSM-05-2017-0100

19. Ali K. A comparative assessment of climate change effect on some of the important tree species of Hindu-Kush Himalayas, using predictive modelling techniques. Int J Adv Res.2015;3(5):1230-40.

20. Yang JB, Li HT, Li DZ, Liu J, Gao LM. Isolation and Characterization of Microsatellite Markers in the Endangered Species Taxus wallichiana Using the FIASCO Method. Hort Sci.2009;44(7):2043-45 https://doi.org/10.21273/HORTSCI.44.7.2043

21. Bhuju S, Gauchan DP. Taxus wallichiana (Zucc.), an Endangered Anti-Cancerous Plant: A Review. Int J Res.2018;5(21):10-21. 
22. ENVIS Centre on Floral Diversity. Hosted by Botanical Survey of India, Kolkata, West Bengal.Sponsored by: Ministry of Environment, Forest \& Climate Change, Govt of India. Available

from: http://www.bsienvis.nic.in/CITES/Taxus \%20wallichiana.pdf

23. India Biodiversity Portal. Available from: https://indiabiodiversity.org/species/show/258690

24. Viet Delta Corporation. Available from: http://herbvietnam.com/

25. Uniyal SK. Bark removal and population structure of Taxus wallichiana Zucc. in a temperate mixed conifer forest of western Himalaya. Environ Monit Assess. 2013;185(4):2921-28. https://doi.org/10.1007/s10661-012-2760-4

26. Malik K, Ahmad M, Zafar M, Ullah R, Mahmood HM, Parveen B, et al. An ethnobotanical study of medicinal plants used to treat skin diseases in northern Pakistan. BMC Complement Altern Med.2019;19(1):210 https://doi.org/10.1186/s12906-019-2605-6

27. Rana PK, Kumar P, Singhal VK, Rana JC. Uses of local plant biodiversity among the tribal communities of Pangi Valley of District Chamba in cold desert Himalaya, India. Scientific World Journal. 2014; 2014:75389. https://doi.org/10.1155/2014/753289

28. Poudel RC, Möller M, Liu J, Gao LM, Baral SR, Li DZ. Low genetic diversity and high inbreeding of the endangered yews in Central Himalaya: implications for conservation of their highly fragmented populations. Biodiversity distrib. 2014;20:1270-84. https://doi.org/10.1111/ddi.12237

29. Thomas P, Farjon A. Taxus wallichiana. The IUCN Red List of Threatened Species 2011: e.T46171879A9730085 http://dx.doi.org/10.2305/IUCN.UK.20112.RLTS.T46171879A9730085.en. Available from: https://www.iucnredlist.org/species/46171879/9730085

30. ENVIS Centre on Floral Diversity Hosted by Botanical Survey of India, Kolkata, West Bengal. Available from: http://www.bsienvis.nic.in/Database/bsi 3949.aspx

31. Nand K, Naithani S. Ethnobotanical uses of wild medicinal plants by the local community in the Asi Ganga sub-basin, Western Himalaya. J Complement Med Res. 2018;9(1):3446. https://doi.org/10.5455/jcmr.20180507034822

32. Singh A, Hart R, Chandra S, Nautiyal MC, Sayok AK. Traditional Herbal Knowledge among the Inhabitants: A Case Study in Urgam Valley of Chamoli Garhwal, Uttarakhand, India. Evid Based Complement Alternat Med.2019;2019:5656925. https://doi.org/10.1155/2019/5656925.

33. Tiwari JK, Dangwal LR, Rana CS, Tiwari P, Ballabha R. Indigenous uses of plant species in Nanda Devi Biosphere Reserve, Uttarakhand, India. Rep Opinion.2010;2(2):67-70.

34. Bhat JA, Kumar M, Bussmann RW. Ecological status and traditional knowledge of medicinal plants in Kedarnath Wildlife Sanctuary of Garhwal Himalaya, India. J Ethnobiol Ethnomed. 2013; 9:1. https://doi.org/10.1186/1746-4269-9-1

35. Phondani PC, Maikhuri RK, Rawat LS, Farooquee NA, Kala CP, Visvakarma SCR, et al. Ethnobotanical Uses of Plants among the Bhotiya Tribal Communities of Niti Valley in Central Himalaya, India. Ethnobot Res Appl.2010;8:233-44.

36. Singh A, Nautiyal MC, Kunwar RM, Bussmann RW. Ethnomedicinal plants used by local inhabitants of Jakholi block, Rudraprayag district, western Himalaya, India. J Ethnobiol Ethnomed.2017;13(1):49. https://doi.org/10.1186/ $\underline{\text { s13002-017-0178-3 }}$

37. Pant S, Samant SS. Ethnobotanical observations in the Mornaula Reserve Forest of Kumaon, West Himalaya, India. Ethnobot leaflets.2010;14:193- 217.
38. Singh KJ, Thakur AK. Medicinal Plants of the Shimla hills, Himachal Pradesh: A Survey. Int J Herb Med.2014;2(2):118127.

39. Rana MS, Samant SS. Diversity, indigenous uses and conservation status of medicinal plants in Manali wildlife sanctuary, North Western Himalaya. Indian J Tradit Knowl.2011;10(3):439- 459.

40. Chauhan PP, Nigam A, Santvan VK. Ethnobotanical study of wild fruits in Pabbar Valley, District Shimla, Himachal Pradesh. J Med Plants Stud.2016;4(2):216- 220.

41. Kumari P, Samant SS, Puri S. Diversity, distribution, indigenous uses and conservation of medicinal plants in central Himachal Pradesh, North Western Himalaya. J Med Plants Stud.2018;6(5):45- 68.

42. Rana D, Bhatt A, Lal B. Ethnobotanical knowledge among the semi-pastoral Gujjar tribe in the high altitude (Adhwari's) of Churah subdivision, district Chamba, Western Himalaya. J Ethnobiol Ethnomed. 2019;15(1):10 https://doi.org/10.1186/s13002-019-0286-3.

43. Rana D, Masoodi HUR. Ethno-botanical survey for wild plants in fringe villages around Shimla Water Catchment Sanctuary, Himachal Pradesh, India. J Apll Nat Sci. 2014;6(2):720-24. https://doi.org/10.31018/jans.v6i2.525

44. Rao PK, Hasan SS, Bhellum BL, Manhas RK. Ethnomedicinal plants of Kathuadistrict, J\&K, India. Ethnopharmacol.2015;171:12-27. https://doi.org/10.1016/j.jep.2015.05.028

45. Kumar R, Bhagat N. Ethnomedicinal plants of district Kathua (J \& K). Int J Med Arom Plants.2012;603-11.

46. Rashid A. Ethnomedicinal plants used in traditional phytotherapy of chest diseases by Gujjar-Bakerwal tribe of district Rajouri of Jammu \& Kashmir state. Int J Pharm Sci Res.2013;4(1):328-33.

47. Seikh MA, Chishti S, Chishti NTN. Medicinally important plants from Ganderbal, Kashmir, India- An ethnomedicinal survey. Eur J Pharm Med Res.2016;3(4):176-83.

48. Ishtiyak P, Hussain SA. Traditional Use of Medicinal Plants among Tribal Communities of Bangus Valley, Kashmir Himalaya, India. Ethno Med.2017;11(4):318-31. https://doi.org/10.1080/09735070.2017.1335123

49. Lone PA, Bhardwaj AK, Shah KW, Tabasum S. Ethnobotanical survey of threatened medicinal plants of Kashmir Himalaya, India. J Med Plant Res. 2014;8(47):136273.

50. Ahmed E, Arshad M, Ahmad M, Saeed M, Ishaque $M$. Ethnopharmacological Survey of Some Medicinally Important Plants of Galliyat Areas of NWFP, Pakistan. Asian J Plant Sci.2004;3(4):410-15. https://doi.org/10.3923/ajps.2004.410.415

51. Ishtiaq $M$, Iqbal $P$, Hussain T.Ethnobotanical uses of gymnosperms of Neelam and Muzaffarabad of Kashmir. Indian J Tradit Knowl.2013;12(3):404-10.

52. Ishtiaq M, Mumtaz AS, Hussain T, Ghani A. Medicinal plant diversity in the flora of Leepa Valley, Muzaffarabad (AJK), Pakistan. Afr J Biotechnol. 2012;11(13):3087-98 http://dx.doi.org/10.5897/AJB11.2711

53. Ahmad KS, Hamid A, Nawaz F, Hameed M, Ahmad F, Deng J, et al. Ethnopharmacological studies of indigenous plants in Kel village, Neelum Valley, Azad Kashmir, Pakistan. J Ethnobiol Ethnomed.2017;13(1):68. https://doi.org/10.1186/ $\underline{\text { s13002-017-0196-1 }}$

54. Ummara U, Bokhari TZ, Altaf A, Younis U, Dasti AA Pharmacological Study of Shogran Valley Flora, Pakistan. International Journal of Scientific \& Engineering Research.2013;4(9):1419-27.

55. Gajurel JP, Srestha KK, Wreth S, Scheidegger C. Taxus wallichiana (Himayalan Yew) for the livelihood of local 
people in some protected areas of Nepal. J Nat Hist Mus. 2014;28:1-8. https://doi.org/10.3126/jnhm.v28i0.14162

56. Rehman HU, Arfan M, Rahman AU, Choudhary MI, Khan AM. Chemical constituents of Taxus wallichiana Zucc. Jour Chem Soc Pak.2003; 25(4):337-40.

57. Sowndhararajan K, Kim S. Influence of Fragrances on Human Psychophysiological Activity: With Special Reference to Human Electroencephalographic Response. Sci Pharm. 2016;84(4):724-51. https://doi.org/10.3390/scipharm84040724

58. Hao J, Guo H, Shi X, Wang Y, Wan Q, Song YB, et al. Comparative proteomic analyses of two Taxus species (Taxus $\times$ media and Taxus mairei) reveals variations in the metabolisms associated with paclitaxel and other metabolites. Plant Cell Physiol.2017;58(11):1878-90. https://doi.org/10.1093/pcp/pcx128

59. Barrales-Cureño HJ, Farrera RA, Reyes RC, Hernández FIY, García AE, Chávez SS. Taxol generalities: a systematic review. Rev Med UV.2016; 16(1):75-91.

60. Shigemori H, Kobayashi J. Biological Activity and Chemistry of Taxoids from the Japanese Yew, Taxus cuspidata. J Nat Prod.2004;67:245-56. https://doi.org/10.1021/np030346y

61. Baloglu E, Kingston DGI. The Taxane Diterpenoids. J Nat Prod.1999;62:1448-72. https://doi.org/10.1021/np990176i

62. Howat S, Park B, Oh IS, Jin YW, Lee EK, Loake GJ. Paclitaxel: biosynthesis,production and future prospects. N Biotechnol.2014;31(3):242-45. https://doi.org/10.1016/j.nbt.2014.02.010

63. Croteau R, Ketchum RE, Long RM, Kaspera R, Wildung MR Taxol biosynthesis and molecular genetics. Phytochem Rev. 2006;5(1):75-97. https://doi.org/10.1007/s11101-005$\underline{3748-2}$

64. Zhou T, Luo X, Yu C, Zhang C, Zhang L, Song YB, et al. Transcriptome analyses provide insights into the expression pattern and sequence similarity of several taxol biosynthesis-related genes in three Taxus species. BMC Plant Biol.2019;19(1):33. https://doi.org/10.1186/s12870-019-1645-x

65. Chattopadhyay SK, Kulshrestha M, Tripathi V, Saha GC, Sharma RP, Mehta VK. Studies on Himalayan Yew Taxus wallichiana: Part IV- The toxoids and phenolic constituents of the roots of Taxus wallichiana. Indian J Chem.1999;70104 .

66. Phu DH, Trong PNH, Hien TTT, Nhan NT.Chemical constituents from the roots of Taxus wallichiana Zucc. J Sci Technol.2013;51(5B):233-37.

67. Khan M, Verma SC, Srivastava SK, Shawl AS, Syamsundar $\mathrm{KV}$, Khanjua SPS, et al. Essential oil composition of Taxus wallichiana Zucc. from the Northern Himalayan region of India. Flavour Fragr J.2006;21:772-75. https://doi.org/10.1002/ffj.1682

68. Bala S, Uniyal GC, Chattopadhyay SK, Tripathi V, Sashidhara KV, Kulshrestha M, et al. Analysis of taxol and major taxoids in Himalayan yew, Taxus wallichiana. J Chromatogr https://doi.org/10.1016/S0021-9673(99)00841-9

69. Vander Velde DG, Georg GI, Gollapudi SR, Jampani HB,Liang XZ, Mitscher LA, et al. Wallifoliol, a taxol congener with a novel carbon skeleton, from Himalayan Taxus wallichiana.J Nat Prod.1994;56:861-67. https://doi.org/10.1021/np50108a032

70. Prasain JK, Stefanowicz P, Kiyota T, Habeichi F, Konishi Y. Taxines from theneedles of Taxus wallichiana. Phytochemistry.2001;58(8):1167-70. https://doi.org/10.1016/S0031-9422(01)00305-3

71. Appendinho G, Ozen HC, Gariboldi O, Torregiani E, Gabetta B, Nizzola R, et al. New oxetane type taxanes from
Taxus wallichiana Zucc. J Chem Soc Perkin Trans I.1993;14:1563-66

https://doi.org/10.1039/P19930001563

72. Barboni L, Gariboldi P, Torregiani E, Appendino G, Varese M, Gabetta B,et al. Minor taxoids from Taxus wallichiana. J Nat Prod. 1995;58(6):934-39. https://doi.org/10.1021/np50120a019

73. Srestha TB, Khatri Chetri SK, Banskota AH, Manandhar MD, Taylor WC. 2-Deacetoxytaxinine B: A New Taxane from Taxus wallichiana. J Nat Prod.1997;60:820-21. https://doi.org/10.1021/np9606153

74. Madhusudan KP, Chattopadhyay SK, Tripathi VK, Sashidhara KV, Kukreja AK, Jain SP.LC-ESI-MS analysis of toxoids from the bark of Taxus wallichiana. Biomed Chromatogr. https://doi.org/10.1002/bmc.163 2002;16:343-55

75. Chattopadhyay SK, Kulshrestha M, Saha GC, Sharma RP, Jain SP, Kumar S. The Taxoid constituents of the heartwood of Taxus wallichiana. Planta Med.1996;62:482. https://doi.org/10.1055/s-2006-957949

76. Joshi BS, Roy R, Chattopadhyay SK, Madhusudanan KP. An NMR and LC-MS based approach for Mixture Analysis involving Taxoid molecules from Taxus wallichiana. J Mol Struct. 2003;235-48. https://doi.org/10.1016/S0022-2860(02)00576-8

77. Chattopadhyay SK, Tripathi V, Sashidhara KV, Mehta VK Studies on Himalayan Yew Taxus wallichiana: Part IX- The chemical constituents of seeds of Taxus wallichiana. Indian J Biochem.2002;41B:225-27.

78. Bush A. Pathophysiological Mechanisms of Asthma. Front Pediatr. https://doi.org/10.3389/fped.2019.00068

2019;7:68

79. Balkrishna A, Sakat SS, Joshi K, Paudel S, Joshi D, Joshi K, et al. Anti-Inflammatory and Anti-Arthritic Efficacies of an Indian Traditional Herbo-Mineral Medicine "Divya Amvatari Ras" in Collagen Antibody-Induced Arthritis (CAIA) Mouse Model Through Modulation of IL-6/IL-13/TNF-a/NFkB Signaling. Front Pharmacol. 2019; 10:659. https://doi.org/10.3389/fphar.2019.00659

80. Bäck M, Yurdagul A Jr, Tabas I, Öörni K, Kovanen PT Inflammation and its resolution in atherosclerosis: mediators and therapeutic opportunities. Nat Rev Cardiol. 2019;16(7):389-406. https://doi.org/10.1038/s41569-019-0169-2

81. Lichota A, Gwozdzinski L, Gwozdzinski K. Therapeutic potential of naturalcompounds in inflammation and chronic venous insufficiency. Eur J Med Chem. 2019;176:68-91.

https://doi.org/10.1016/i.ejmech.2019.04.075

82. Tsalamandris S, Antonopoulos AS, Oikonomou E, Papamikroulis GA, Vogiatzi G, Papaioannou S, et al. The Role of Inflammation in Diabetes: Current Concepts and Future Perspectives. Eur Cardiol.2019;14(1):50-59. https://doi.org/10.15420/ecr.2018.33.1.

83. Abufaraj M, Tabung FK, Shariat SF, Moschini M, Devore E, Papantoniou K, et al. Association between Inflammatory Potential of Diet and Bladder Cancer Risk: Results of 3 United States Prospective Cohort Studies. I Urol 2019;202(3):484-89. https://doi.org/10.1097/JU.0000000000000279

84. Oguntibeju OO. Medicinal plants with anti-inflammatory activities from selected countries and regions of Africa. J Inflamm Res. https://doi.org/10.2147/JIR.S167789

2018;11:307-17.

85. Khan I, Nisar M, Shah MR, Shah H, Gilani SN, Gul F, et al.Anti-inflammatory activities of Taxusabietane A isolated from Taxus wallichianaZucc. Fitoterapia.2011;82(7):100307. https://doi.org/10.1016/j.fitote.2011.06.003 
86. Qayum M, Nisar M, Shah MR, Adhikari A, Kaleem WA, Khan I, et al. Analgesic and antiinflammatory activities of toxoids from Taxus wallichiana Zucc. Phytother Res.2012;26(4):552-56. https://doi.org/10.1002/ptr.3574

87. Khan I, Nisar M, Zarrelli A, Fabio GD, Gul F, Gilani SN, et al. Molecular insights to explore abietane diterpenes as new LOX inhibitors. Med Chem Res.2013;22(12):5809-13. https://doi.org/10.1007/s00044-013-0559-7

88. Nisar M, Khan I, Simjee SU, Gilani AH, Obaidullah, Perveen $\mathrm{H}$. Anticonvulsant, analgesic and antipyretic activities of Taxus wallichiana Zucc. J Ethnopharmacol.2008;116(3):49094. https://doi.org/10.1016/j.jep.2007.12.021

89. Bhat MA, Ganie SA, Dar KB, Ali R, Hamid R. Invitro antioxidant potential and hepatoprotective activity of Taxus wallichiana. Asian J Pharm Clin Res.2018;11(8):23743. https://doi.org/10.22159/ajpcr.2018.v11i8.22345

90. Chattopadhyay SK, Pal A, Maulik PR, Kaur T, Garg A, Khanuja SP. Taxoid fromthe needles of the Himalayan yew Taxus wallichiana with cytotoxic andimmunomodulatory activities. Bioorg Med Chem Lett.2006;16(9):2446-49. https://doi.org/10.1016/j.bmcl.2006.01.077

91. Chattopadhyay SK, Kumar TR, Maulik PR, Srivastava S, Garg A, Sharon A, et al. Absolute configuration and anticancer activity of taxiresinol andrelated lignans of Taxus wallichiana. Bioorg Med Chem.2003;11(23):4945-48. https://doi.org/10.1016/j.bmc.2003.09.010

92. Khan I, Nisar M, Ahmad M, Shah H, Iqbal Z, Saeed M, et al. Molecular simulations of Taxawallin I inside classical taxol binding site of $\beta$-tubulin. Fitoterapia.2011;82(2):276-81. https://doi.org/10.1016/j.fitote.2010.10.011

93. Wang $\mathrm{Y}$, Wang J, Wang $\mathrm{H}$, Ye W. Novel taxane derivatives from Taxus wallichiana with high anticancer potency on tumor cells. Chem Biol Drug Des.2016;88(4):556-61. https://doi.org/10.1111/cbdd.12782

94. Zwawiak J, Zaprutko L. A brief history of taxol.J Med Sci.2014;1(83):47-52.

95. Weaver BA. How Taxol/paclitaxel kills cancer cells. Mol Biol Cell. 2014;25(18):2677-81. https://doi.org/10.1091/mbc.e14-04-0916

96. Kellogg EH, Hejab NMA, Howes S, Northcote P, Miller JH, Fernando Diaz J, et al. Insights into the distinct mechanisms of action of taxane and non-taxane microtubule stabilizers from cryo-EM structures. J Mol Biol.2017;429(5):633-46.

https://doi.org/10.1016/j.jmb.2017.01.001

97. Mukhtar E, Adhami VM, Mukhtar H. Targeting microtubules by natural agents for cancer therapy. Mol Cancer Ther.2014;13(2):275-84 https://doi.org/10.1158/1535-7163.MCT-13-0791

98. Yanamadala G, Praveen srikumar P, Rushyendra GV, Gupta VRM, Srinivasarao S. Development and validation of a novel RP-HPLC method for the determination of cabazitaxel in bulk and formulations. Indo Am J Pharm Res. 2013; 3(10):8266-72.

99. Bidkar AP, Sanpui P, Ghosh SS. Efficient induction of apoptosis in cancer cells by paclitaxel-loaded selenium nanoparticles. Nanomedicine (Lond). 2017;12(21):2641-51. https://doi.org/10.2217/nnm-2017-0189

100. Brewer JR, Morrison G, Dolan ME, Fleming GF. Chemotherapy-induced peripheral neuropathy: Current status and progress. Gynecol Oncol. 2016;140(1):176-83 https://doi.org/10.1016/j.ygyno.2015.11.011

101. Sun J, Jiang L, Lin Y, Gerhard EM, Jiang X, Li L, et al. Enhanced anticancer efficacy of paclitaxel through multistage tumor-targeting liposomes modified with RGD and KLA peptides. Int J Nanomedicine. 2017;12:1517-37. https://doi.org/10.2147/IJN.S122859
102. Mcllwain DR, Berger T, Mak TW. Caspase functions in cell death and disease. Cold Spring Harb Perspect Biol. 2015; 7(4):a026716. Erratum In: Cold Spring Harb Perspect Biol. 2015;5(4). pii: a008656 https://doi.org/10.1101/cshperspect.a026716

103. Jelínek M, Balušíková K, Schmiedlová M, NěmcováFürstová V, Šrámek J, Stančíková J, et al. The role of individual caspases in cell death induction by taxanes in breast cancer cells. Cancer Cell Int.2015;15(1):8 https://doi.org/10.1186/s12935-015-0155-7

104. Yao Y, Marassi FM. Reconstitution and Characterization of BCL-2 Family Proteins in Lipid Bilayer Nanodiscs. Methods Mol Biol. 2019;1877:233-46 https://doi.org/10.1007/978-1-4939-8861-7_16

105. Tessoulin B, Papin A, Gomez-Bougie P, Bellanger C, Amiot M, Pellat-Deceunynck C, et al. BCL2-Family Dysregulation in B-Cell Malignancies: From Gene Expression Regulation to a Targeted Therapy Biomarker. Front Oncol.2019;8: 645. https://doi.org/10.3389/fonc.2018.00645

106. Correia C, Lee SH, Meng XW, Vincelette ND, Knorr KL, Ding $\mathrm{H}$, et al. Emerging understanding of Bcl-2 biology: Implications for neoplastic progression and treatment. Biochim Biophys Acta.2015;1853(7):1658-71. https://doi.org/10.1016/j.bbamcr.2015.03.012

107. Hientz K, Mohr A, Bhakta-Guha D, Efferth T. The role of p53 in cancer drug resistance and targeted chemotherapy. Oncotarget. https://doi.org/10.18632/oncotarget.13475

108. Simabuco FM, Morale MG, Pavan ICB, Morelli AP, Silva FR, Tamura RE. p53 and metabolism: from mechanism to therapeutics. Oncotarget. 2018;9(34):23780-823. https://doi.org/10.18632/oncotarget.25267

109. Georgakilas AG, Martin OA, Bonner WM. p21:A Two-Faced Genome Guardian. Trends Mol Med.2017;23(4):310-19. https://doi.org/10.1016/j.molmed.2017.02.001

110. Lv C, Qu H, Zhu W, Xu K, Xu A, Jia B, et al. Low-Dose Paclitaxel Inhibits Tumor Cell Growth by Regulating Glutaminolysis in Colorectal Carcinoma Cells. Front Pharmacol. https://doi.org/10.3389/fphar.2017.00244

111. Wehner F, Gawatz O. [Suicidal yew poisoning--from Caesar to today--or suicide instructions on the internet]. Arch Kriminol.2003;211(1-2):19-26.

112. Kobusiak-Prokopowicz M, Marciniak A, Ślusarczyk S, Ściborski K, Stachurska A, Mysiak A, et al. A suicide attempt by intoxication with Taxus baccata leaves and ultra-fast liquid chromatography-electrospray ionizationtandem mass spectrometry, analysis of patient serum and different plant samples: case report. BMC Pharmacol Toxicol. 2016;17(1):41. https://doi.org/10.1186/s40360-016$\underline{0078-5}$

113. Piskač O, Stříbrný J, Rakovcová H, Malý M. Cardiotoxicity of yew. Cor et Vasa. 2015;57(3):e234-e238. https://doi.org/10.1016/j.crvasa.2014.11.003

114. Perju-Dumbravă D, Morar S, Chiroban O, Lechintan E, Cioca A. Suicidal poisoning by ingestion of Taxus Baccata leaves. Case report and literature review. Rom J Leg Med. 2013;21:115-18. https://doi.org/10.4323/rjlm.2013.115

115. Willaert W, Claessens P, Vankelecom B, Vanderheyden M. Intoxication with Taxus baccata: cardiac arrhythmias following yew leaves ingestion. Pacing Clin. Electrophysiol. 2002;25(4 Pt 1):511-12. $\quad$ https://doi.org/10.1046/j.14609592.2002.00511.X

116. Poudel RC, Möller M, Gao LM, Ahrends A, Baral SR, Liu J, et al. Using morphological, molecular and climatic data to delimitate yews along the Hindu Kush-Himalaya and adjacent regions. PLoS One. 2012;7(10):e46873. https://doi.org/10.1371/journal.pone.0046873 
117. Eibl R, Meier P, Stutz I, Schildberger D, Hühn T, Eibl D. Plant cell culture technology in the cosmetics and food industries: current state and future trends. Appl Microbiol Biotechnol.

2018;102(20):8661-75 https://doi.org/10.1007/s00253-018-9279-8

118. Dutta MM, Jha S. Embryo Culture of Taxus wallichiana Zucc. J Plant Biotechnol.2004;6(4):213-19.

119. Hussain A, Qarshi IA, Nazir H, Ullah I, Rashid M, Shinwari ZK. In-vitro callogenesis and organogenesis of Taxus wallichiana. Pak J Bot.2013;45(5):1755-59.

120. Datta MM, Majumder A, Jha S. Organogenesis and plant regeneration in Taxus wallichiana (Zucc.). Plant Cell Rep. 2006;25(1):11-18. https://doi.org/10.1007/s00299-005-0027-z

121. Aslam M, Raina PA, Rafiq RU, Siddiqi TO, Reshi ZA. Adventitious root formation in branch cuttings of Taxus wallichiana Zucc.(Himalayan yew): A clonal approach to conserve the scarce resource. Curr Bot.2017;8:127-35 https://doi.org/10.19071/cb.2017.v8.3231

122. Nazir N, Kamili AN, Shah D, Zargar MY. Adventitious Rooting in Shoot Cuttings of Taxus wallichiana Zucc., an Endangered Medicinally Important Conifer of Kashmir Himalaya.Forest Res. 2018;7:2. https://doi.org/10.4172/21689776.1000221

123. Veeresham C, Mamatha CH, Babu P, Srisilam K, Kokate CK. Production of Taxol and its Analogues from Cell Cultures of Taxus wallichiana. Pharm Biol.2003;41(6):426-30. https://doi.org/10.1076/phbi.41.6.426.17822

124. Das K, Dang R, Ghanshala N, Rajashekharan PE. In vitro establishment and maintenance of callus of Taxus wallichiana Zucc. for production of secondary metabolites. Nat Prod Rad.2008;7(2):150-53.

125. Navia-Osorio A, Garden H, Cusidó RM, Palazón J, Alfermann AW, Piñol MT. Production of paclitaxel and baccatin III in a 20-L airlift bioreactor by a cell suspension of Taxus wallichiana. Planta Med. 2002;68(4):336-40. https://doi.org/10.1055/s-2002-26739

126. Barbuti AM, Chen ZS. Paclitaxel Through the Ages of Anticancer Therapy: Exploring Its Role in Chemoresistance and Radiation Therapy. Cancers (Basel). 2015;7(4):2360-71. https://doi.org/10.3390/cancers7040897
127. Zhang D, Yang R, Wang S, Dong Z. Paclitaxel: new uses for an old drug. Drug Des Devel Ther.2014;8:279-84. https://doi.org/10.2147/DDDT.S56801

128. Kajani AA, Zarkesh-Esfahani SH, Bordbar AK, Khosropour AR, Razmjou A, Kardi M. Anticancer effects of silver nanoparticles encapsulated by Taxus baccata extracts. J Mol Liq. 2016;223:549-56. https://doi.org/10.1016/j.molliq.2016.08.064

129. Dutta S, Mariappan G, Sarkar D, Sarkar P. Assessment of Anti-inflammatory Activity of Taxus Baccata Linn. Bark Extract. Anc Sci Life.2010;29(3):19-21.

130. Patel P, Patel K, Gandhi T. Evaluation of Effect of Taxus baccata Leaves Extract on Bronchoconstriction and Bronchial Hyperreactivity in Experimental Animals. J Young Pharm. 2011;3(1):41- 47. https://doi.org/10.4103/0975-1483.76418

131. Shang W, Qiao J, Gu C, Yin W, Du J, Wang W, et al. Anticancer activity of an extract from needles and twigs of Taxus cuspidata and its synergistic effect as a cocktail with 5-fluorouracil. BMC Complement Altern Med. 2011;11:123. https://doi.org/10.1186/1472-6882-11-123

132.Ekor M. The growing use of herbal medicines: issues relating to adverse reactions and challenges in monitoring safety. Front Pharmacol.2014;4:177. https://doi.org/10.3389/ fphar.2013.00177

133. Datta T, Patra AK, Dastidar SG. Medicinal plants used by tribal population of Coochbehar district, West Bengal, India-an ethnobotanical survey. Asian Pac J Trop Biomed.2014;4(Suppl 1):S478-S482. https://doi.org/10.12980/ APJTB.4.2014C1122

134. Xie DF, Li MJ, Tan JB, Price M, Xiao QY, Zhou SD, et al. Phylogeography and genetic effects of habitat fragmentation on endemic Urophysa (Ranunculaceae) in Yungui Plateau and adjacent regions. PLoS One. 2017;12(10):e0186378. https://doi.org/10.1371/journal.pone.0186378

135. Keller LF, Waller DM. Inbreeding effects in wild populations. Trends in Ecology \& Evolution. 2002;17(5):230-41 